\title{
The Future of Capital Income Taxation
}

\author{
Alan J. Auerbach* \\ University of California, Berkeley
}

September 4, 2006

\footnotetext{
* This paper was prepared for the 2006 Institute for Fiscal Studies Annual Lecture. I am grateful to Anne Moore for research assistance and to Ethan Auerbach, Len Burman, Michael Graetz, Jim Hines, Joel Slemrod, and Al Warren for helpful discussions and suggestions.
} 
Despite our limitations as forecasters, economists are prone to thinking about the future. A declining number of economists see a future for capital income taxation. The disenchantment with capital income taxes is not new, of course. Joseph Pechman's 1990 presidential address to the American Economic Association had a title similar to mine ('The Future of the Income Tax'), and took on many of the issues I will address here. Pechman concluded that 'there is no good reason for the disenchantment of economists with the income tax. The main rival of the income tax - the consumption expenditure tax - is distinctly inferior on theoretical as well as practical grounds. ${ }^{1}$

In light of what we know today, I cannot agree with either of Pechman's conclusions. We have accumulated many good reasons to be disenchanted with the income tax, and the case for the consumption expenditure tax is not easily dismissed. Indeed, the case against capital income taxation is stronger now than when Pechman wrote, given the difficulty of collecting capital income taxes in a world of financial innovation and capital mobility.

But capital income taxes are still with us, and it is useful to consider why this is so, and what role capital income taxes might play in a world with increasingly integrated capital markets. Explaining why an individual country might still seek to collect capital income taxes is difficult, but I feel particularly well suited to the task. As a resident of Berkeley, California, I live in a city that historically has conducted its own independent foreign policy, and in a state whose popular two-term governor, while debating his opponent in a successful campaign to be U.S. president, claimed to have used state fiscal policy to reduce the inflation rate in California. ${ }^{2}$

\footnotetext{
${ }^{1}$ Pechman, 1990, p. 17.

${ }^{2}$ In the October 28, 1980 Carter-Reagan presidential debate, Ronald Reagan said of his proposals for cutting U.S. federal spending and taxes: 'We have a program for a gradual reduction of Government spending based on these theories, and I have a task force now that has been working on where those cuts could be made. I'm confident that it can be done and that it will reduce inflation because I did it in California. And inflation went down below the national average in California when we returned the money to the people and reduced Government spending.'
} 
I will organize my comments around several facts about the state of capital income taxation today. After presenting these facts, I will consider what they suggest about the future of capital income taxation. ${ }^{3}$ Ultimately, I conclude that capital income taxes will remain and that much productive discussion remains about what form they should take.

\section{Facts about capital income taxation}

The first relevant fact about capital income taxation today is that there is capital income taxation today.

\section{Capital income taxes haven't gone away}

Capital income taxes include taxes collected from individuals and from businesses, including corporations. Figure 1 presents the share of federal revenues accounted for by corporate income taxes among the G-7 countries for the period 1973-2004. Several points are noteworthy here. First, over the full period there appears to have been a downward trend in the importance of corporate tax collections, as six of the seven countries (all but France) experienced declines in shares. Whether this trend continues is unclear; corporate taxes have actually risen as a share of revenue over the past two decades in the United States and Canada, for example. Second, there has been some convergence in these shares; the three countries with the largest initial shares, Japan, the United States, and Canada, experienced the largest declines over the period. Third, corporate tax revenues still account for between 10 and 25 percent of federal revenues for all but one (Germany) of the G-7 countries. If one adds in personal capital income

\footnotetext{
Commission on Presidential Debates, Debate Transcript October 28, 1980. URL: www.debates.org/pages/trans80b_p.html.

${ }^{3}$ In considering these issues, I have drawn on my own recent review (Auerbach, 2006a) and benefited from a number of other recent surveys on the subject, including Zodrow (2005) and Sørensen (2006).
} 
taxes, which are harder to measure precisely because one must determine the share of personal income taxes attributable to capital income, then it is evident that capital income taxes remain significant in the world's leading economies.

In light of the substantial revenues we collect from taxing capital income, it is worth commenting on some recent empirical studies that have suggested we collect little from doing so. ${ }^{4}$ These papers do not estimate the revenue effects of eliminating all capital income taxes, but rather of eliminating capital income taxes at the individual level and replacing the corporate income tax with a corporate cash-flow tax, which raises nearly as much or more revenue than the existing corporate income tax. Thus, what they really show is that we don't raise that much money from the taxes we impose on individuals, taking into account related deductions and taxfavored savings. Simply eliminating the corporate income tax would result in a substantial revenue loss. I return to this distinction below.

\section{Capital income taxes have changed form}

While corporate income taxes remain an important source of revenue, the tax structure typically used to raise this revenue has changed. As highlighted by Devereux et al. (2002) in research conducted at the Institute for Fiscal Studies, there has been a tendency for statutory corporate tax rates to decline over time, as illustrated in Figure 2, but also for investment-related deductions to decline, resulting in a less obvious trend in marginal effective tax rates, as shown in Figure 3. A potential explanation is increasing tax competition, although in a more subtle form than simply through a reduction in marginal effective tax rates.

While the marginal effective tax rate may determine the level of investment, given the choice of location, location decisions depend on the taxation of inframarginal rents as well.

\footnotetext{
${ }^{4}$ See Gordon et al. (2004) for the United States and Becker and Fuest (2005) for Germany.
} 
Thus, countries competing for enterprises may wish to lower taxes on rents - and hence the statutory tax rate - rather than taxes on investment, depending on the relative sensitivity of investment and location decisions. This tendency to reduce the tax burden on rents rather than on fixed capital is further encouraged by the practice of profit shifting, in which multinational enterprises use the mechanism of internal transfer pricing to locate profits, for tax purposes, in jurisdictions with low statutory tax rates.

One can't say for sure that these structural corporate tax changes are the result of heightened tax competition, but the empirical evidence makes it very clear that corporations respond to the tax incentives when deciding where to locate, invest and report profits. ${ }^{5}$ This responsiveness suggests that the cost any given country faces in taxing corporate source income has risen with the rise of multinational activity, regardless of the extent to which national tax systems have adjusted to this reality.

\section{Financial activities account for an increasing share of corporate activity}

Economists modeling the activities of corporations often envision a company raising funds to finance investment in plant and equipment. More and more, though, corporations are financial entities, acting as intermediaries rather than as the ultimate destination of funds. It is no longer an innocuous simplification, if it ever was, to omit financial companies from our analysis - they account for too large a share of corporate activity and tax revenue. Figure 4 shows that financial companies, which accounted for around 5 percent of U.S. corporate tax revenues and 11 percent of UK corporate tax revenues in 1983, paid over one quarter of all corporate taxes in each country two decades later; and this share excludes financial activities of companies having some financial operations but still classified as "non-financial."

\footnotetext{
${ }^{5}$ Gordon and Hines (2002) survey this evidence.
} 
The rising importance of financial activities has two important implications for the future of capital income taxation. First, to the extent that financial companies have greater flexibility in responding to tax incentives, particularly with respect to the location of their activities (it is, after all, easier to move electrons than cement), the difficulty of chasing capital income in order to tax it can only get harder. Second, tax systems designed for nonfinancial companies may not work especially well when applied to the financial sector. As I discuss below, this shift has particular consequences regarding the alternatives to our current system of capital income taxation.

\section{Innovations in finance and accounting have produced 'hybrid vigor'}

As economists, we tend to model responses to taxation as representing meaningful changes in economic behavior. Adoption of a new tax policy may induce a change in the level of investment or a shift in the location of that investment. Even if the response is on the financial side, a substitution of debt for equity as a source of funds, for example, we think of these securities as having different attributes regarding risk and legal rights, so that a real economic change is involved. The change may not be for the good, of course, but the fact that a real change in activity is involved imposes a limit on the extent of the taxpayer response - one can do with only so many DeLorean car plants in Northern Ireland, regardless of the fiscal incentives. But, through innovations in the design of financial instruments and the organization of corporate entities, it has become increasingly possible to gain tax advantages using paper transactions largely detached from significant economic responses. ${ }^{6}$

\footnotetext{
${ }^{6}$ Slemrod (1992) makes a somewhat different distinction along these lines, separating "real" responses on one hand from accounting and financial responses on the other. But the key point in each instance is to draw a line between responses that require a significant change in economic activity and those that do not. A second distinction may involve government intent, in that governments seeking to induce substantive changes in economic activity may instead elicit changes in the characterization of existing activities.
} 
Two types of significant recent activity involve the use of so-called 'hybrid' structures: hybrid securities and hybrid entities. In each case, the term hybrid is used to denote an inconsistency in characterization. Hybrid securities are seen as somewhere between equity, as for example in determining bond ratings, but for tax purposes are treated as debt, allowing the issuer to deduct payments. Hybrid entities are corporations whose ownership structure is viewed inconsistently by different countries, to the benefit of corporate taxpayers. Neither structure derives from any evident tax policy objective, but both structures reflect the complexity of modern corporate income taxation. Hybrid securities result from attempts to draw a sharp distinction between debt and equity in a world where securities can be carefully tailored to fill any space that remains between the two. Hybrid entities result from international differences in the classification of corporate entities. ${ }^{7}$

Hybrids are complex and esoteric, but their existence is a matter that should concern not just financial engineers, tax lawyers and botanists. As Figure 5 shows, issues of hybrid securities with deductible payments in the United States have recently been of a magnitude similar to common equity issues. As to hybrid entities, their growth has added an important dimension to international tax avoidance, leading at least some to argue that the declining tax burdens of multinationals result no longer from the tax policy actions of competing governments, but from the increased tax avoidance of the multinationals themselves. ${ }^{8}$

\footnotetext{
${ }^{7}$ Hybrid entities grew out of the so-called "check-the-box" regulations adopted by the United States in 1997. Under these regulations, originally designed to simplify tax filing for certain domestic entities, U.S. parent corporations can treat subsidiaries in high-tax jurisdictions as branches of subsidiaries in low-tax jurisdictions even though such subsidiaries may be viewed as distinct by the high-tax jurisdiction. The result is that payments that are tax deductible in the high-tax jurisdiction are not immediately taxable by the United States, contrary to their treatment had the entities been viewed as distinct. See Altshuler and Grubert (2005) for further discussion.

${ }^{8}$ See Altshuler and Grubert (2005). Under 2006 legislation, the United States has now made it possible to achieve similar results even without utilizing the structure of hybrid entities.
} 
One might also point to a third type of hybrid, at least in the United States, the company that has important corporate attributes such as limited liability and capital market access but is not taxed as a corporation. Of such forms, the most important close substitute in the United States is the S corporation, ${ }^{9}$ which may have no more than 100 shareholders and only one class of common stock, and in exchange delivers its owners from all corporate-level taxation. The steady rise in the importance of S corporations, as shown in Figure 6, reflects more than just variations in the relative taxation of corporate and non-corporate entities, but there is evidence that the choice is responsive to taxation, at least among smaller companies for which the restrictions imposed by $\mathrm{S}$ corporation status are less binding. ${ }^{10}$

\section{Strong corporate tax revenues may reflect an increasing dispersion of profitability}

As Figure 1 illustrated, corporate tax revenues haven't disappeared. In fact, they've done rather well in the last few years. In the United States, for example, corporate taxes accounted for a higher share of federal revenues in 2005 than in any year since 1979. This has surprised many observers in light of the apparent strengthening of tax competition and tax avoidance. But other economic changes appear to be at work as well. One that has received relatively little notice is the increasing dispersion of outcomes among corporations. In the United States, for example, the average tax rate on net corporate profits has increased substantially simply because so many companies have experienced losses. ${ }^{11}$ With positive income subject to tax and losses to a considerable extent ignored by the tax system, the average tax rate on positive income net of losses can be quite high when losses are large relative to positive income. Figure 7 shows losses relative to positive income for U.S nonfinancial corporations since 1980. One sees the expected

\footnotetext{
${ }^{9}$ The designation refers to the relevant subchapter of the Internal Revenue Code.

${ }^{10}$ See Auerbach and Slemrod (1997).

${ }^{11}$ See Auerbach (2006b).
} 
cyclical pattern, with local peaks in the recession years of 1982 and 1991, but there is no historical precedent for what has happened in recent years, when losses approached 80 percent of income in the wake of a mild recession and have remained high even during the subsequent recovery. This pattern is consistent with a recent increase in the dispersion of corporate outcomes that has been observed in the United States, ${ }^{12}$ but it is unclear whether the phenomenon is more widespread internationally, what has caused it, and whether it is a permanent or temporary phenomenon.

The asymmetric treatment of gains and losses makes corporate tax systems more distortionary than they otherwise would be by presenting firms with different incentives to invest according to their tax status and altering investment choices. ${ }^{13}$ This has long been understood without leading to any significant policy responses, but if increased dispersion is here to stay, then the distortions associated with tax asymmetries will be more severe than in the past. In this event, the resulting strength of tax revenues would signal a greater need for reform, rather than that all is well.

\section{International coordination of capital income taxation has been difficult to accomplish}

One natural response to increasing capital mobility and international tax competition has been the pursuit of international agreements seeking to coordinate tax rates and other tax policies. Whether this coordination is a good idea or not is open to question, as unbridled tax competition can have positive as well as negative effects. ${ }^{14}$ But several factors have hindered tax coordination. First and most obviously, national objectives differ. For example, a country with low revenue requirements and a desire to attract capital may have no interest in raising its

\footnotetext{
${ }^{12}$ See Comin and Philippon (2005).

${ }^{13}$ See Auerbach $(1983,1986)$.

${ }^{14}$ See Wilson (1999).
} 
corporate tax rate to please other countries. The extent to which such differences should be permitted, and how one might distinguish between harmful and beneficial types of tax competition, are difficult questions. Second, the rules and objectives of international agreements often make little sense from an economic perspective, introducing arbitrary distinctions and limits on policy choices. For example, the rules of the World Trade Organization (WTO), originally developed under the General Agreement on Tariffs and Trade (GATT), permit the provision of rebates on exports for indirect taxes (taxes on transactions) such as the value added tax (VAT), but prohibit such rebates as export subsidies under otherwise equivalent direct taxes (taxes on individual or corporate taxpayers). More recently, the European Commission's Code of Conduct for the European Union, following the reasoning of the OECD's 'harmful tax practices' project, prohibits member countries from providing preferential tax rates to nonresident investors. ${ }^{15}$ This means that a member country cannot implement a system of pure residence-based taxation that eschews source-based capital income taxes, even though this is precisely what various results in the economics literature tell them to do. ${ }^{16}$ Finally, the translation of existing international agreements into restrictions on specific policies is quite complex and unpredictable, as some of the surprising recent rulings of the European Court of Justice illustrate. $^{17}$

In short, countries are likely to have different interests in the formulation of international tax agreements; the motivation for existing agreements is not always evident; and their application may serve to limit the adoption of generally beneficial tax policies.

\footnotetext{
${ }^{15}$ See Graetz and Warren, 2006, p. 1222.

${ }^{16}$ See Gordon and Hines (2002) for discussion of this result, which ultimately is traceable to the work of Diamond and Mirrlees (1971) on production efficiency.

${ }^{17}$ See Graetz and Warren (2006) and Bond, Gammie, and Mokkas (2006).
} 


\section{Summary}

So, where does this collection of facts about capital income taxation leave us? We are still able to collect capital income taxes. Tax systems appear to have adapted to increases in capital mobility and improvements in the technology of avoidance, but these changes still may make capital income taxes a less desirable source of revenue. Economic changes such as the growth of financial services and the dispersion of corporate profitability present additional challenges to existing corporate tax rules. And international coordination thus far has fallen far short of producing a sensible system of restrictions on independent capital income tax policies.

The option is open to us to muddle through, to attempt to deal with new challenges as they occur by modifying existing tax rules, as we have in the past. But should we choose simply to plod ahead, even if it is feasible to do so? Some might conclude that, to paraphrase Churchill, our current form of taxation is the worst form except all the others that have been tried. But others could point out that there are some alternatives that haven't been tried, and which therefore may still deserve consideration.

\section{Alternatives}

As Pechman noted in his 1990 address, many would replace the current income tax with a consumption expenditure tax. It is particularly appropriate to consider this and other alternatives here, given that we have been meeting in preparation of activities to mark the $30^{\text {th }}$ anniversary of one of the major contributions of the Institute for Fiscal Studies, the report of the Meade

Committee $^{18}$, which provided a detailed analysis of expenditure tax alternatives to the income

\footnotetext{
${ }^{18}$ Institute for Fiscal Studies (1978).
} 
tax. Is adoption of an expenditure tax more likely now than in 1978, or more desirable, and what of other alternatives that have appeared in the years before and since?

\section{The road not taken}

Capital income is difficult to measure and capital income taxes are difficult to collect. Moreover, economic research has shown us that, even under ideal circumstances with regard to measurement and collection, we might wish not to have capital income taxes at all, especially in the long run, because of their extreme distortion of saving decisions ${ }^{19}$, and that we don't necessarily need to use capital income taxes to satisfy the requirements of equity and social justice. ${ }^{20}$ It might seem, then, that modifying our current system simply by eliminating capital income taxes would be desirable.

This outcome, however, is not likely, nor is it particularly desirable. Capital income has different pieces, including returns to risk-taking, prior investments and firm-specific economic rents. Only a small portion of the measured return to capital represents the normal return to new saving that our theories tell us not to tax. Eliminating all taxes on capital income gives up much more revenue than simply eliminating the tax on the normal return to new saving, and does little for the cause of equity, in fact and in appearance. Further, having no tax at all on capital income while maintaining a tax on labor income puts considerable pressure on the distinction between labor and capital income.

While there certainly have been moves toward reduced taxes on capital income, complete elimination does not seem on the agenda, nor should it be.

\footnotetext{
${ }^{19}$ See Judd (1985) and Chamley (1986).

${ }^{20}$ See Atkinson and Stiglitz (1976).
} 


\section{The many types of consumption tax}

As the Meade Committee report elucidated, it is not necessary to eliminate capital income taxes in order to reduce or eliminate the tax-induced distortion of saving and investment decisions. All that is necessary is to eliminate the tax on the normal return to capital, and this can be accomplished using some form of consumption taxation.

Unlike elimination of capital income taxes, consumption taxes continue to tax the returns to capital other than the normal return to saving, thus limiting the revenue loss and the windfalls to capital owners resulting from the policy change. But there are many types of consumption tax and many dimensions in which the types differ. Depending on the type of consumption tax, adoption of a consumption tax would address some of the problems associated with capital income taxation that I have mentioned above, but would leave other problems unaffected and exacerbate still others.

\section{A. Timing}

A capital income tax taxes capital income. A consumption tax taxes capital income as well, but also provides an offsetting deduction for investment that has the effect of canceling the impact of the income tax on the normal return to capital. But the deduction and the tax occur at different times, and so the offset works only if the tax rate remains constant, or at least is expected to remain constant when investment decisions are made. Anticipated tax rate increases or decreases could cause substantial swings in investment incentives under a consumption tax. This is true even today, given that consumption taxes already exist, but the effects would be much more significant if consumption tax rates were raised to provide enough revenue to replace the existing capital income taxes. 
There are alternatives to the standard approach to consumption taxation that would let investors deduct the cost of investment over time rather than right away, providing interest on investment balances not yet deducted in order to offset the delay. ${ }^{21}$ But this approach would give up one of the important simplifications of the consumption tax, elimination of the need to keep track of asset basis over time. Also, this approach would be rather difficult to integrate into certain types of consumption tax, such as a VAT or a retail sales tax.

\section{B. Financial assets and liabilities}

The simplest form of consumption tax utilizes what the Meade Committee called the $R$ base, ignoring financial assets and liabilities and the associated interest payments. This approach, basically the one followed by existing VATs, has a major advantage over the current system of capital income taxation in that it treats debt and equity capital alike; issuing debt instead of equity would no longer have an impact on the firm's tax position, and the incentives to develop and finance with hybrid securities would go away. But the $R$ base has a big disadvantage as well: it ignores the profits of financial companies. As discussed earlier, the profits of financial companies have become too important to ignore, so some alternative must be found. Countries with VATs have come up with different alternatives, but none fits perfectly into the $R$ base system.

A more comprehensive solution to the taxation of financial companies is to adopt what the Meade Committee called the $R+F$ base, treating financial assets just like other assets and thereby taxing the profits of financial companies in the same manner as other companies, but this

\footnotetext{
${ }^{21}$ Such an approach was proposed by Bradford (1998). It is closely related to the Allowance for Corporate Equity (ACE) approach analyzed by Boadway and Bruce (1984) and Bond and Devereux (1995), which would provide a deduction for the normal rate of return on equity rather than on all corporate capital while maintaining existing treatment of debt-financed investments.
} 
approach does not treat debt and equity equally, so some of the current incentives to manipulate the characterization of securities would remain. ${ }^{22}$

\section{Tax losses}

The asymmetric treatment of gains and losses is an unattractive feature of the current income tax, made worse by an increased incidence of losses, as has occurred in the United States in recent years. One might think this problem would disappear under a consumption tax, given that consumption is never negative. But what we call 'consumption taxes' are really a family of taxes that are similar to consumption taxes, and some can produce negative tax bases. Indeed, some are more likely to do so than the current system of capital income taxation. This is another consequence of the timing differences of deductions and income.

The problem of losses under a consumption tax is reduced if deductions are delayed to coincide with income, but as discussed this makes the tax system more complex. The problem of losses is also reduced if companies are taxed not only on their capital income, but also on their labor costs, as is true under a VAT. But taxing labor costs at the business level limits the scope for making the tax system progressive.

\section{International coordination}

Perhaps at the next meeting of the WTO, protesters of globalization, child labor, genetically modified foods and McDonald's will be joined by tax reformers frustrated by international agreements that limit our ability to adopt perfectly sensible tax reforms. VATs pass the test, but other border-adjustable taxes - systems that provide a tax rebate for exports and impose a tax on imports - might not, if they have a direct tax component, that is, a tax on

\footnotetext{
${ }^{22}$ See Auerbach (2006a)
} 
individual taxpayers rather than on transactions. This can be a serious impediment to realistic tax reform because, as I will discuss shortly, direct taxes are important to achieving a progressive tax system. Indeed, the recent U.S. Presidential Tax Reform Panel was forced to confront the issue of border adjustments with respect to one of its two proposals that had a consumption tax at its core. $^{23}$

There are good and bad reasons for seeking to implement border adjustments under a consumption tax. A bad reason is that border adjustments promote exports. This is a bad reason because it is incorrect. ${ }^{24}$ A good reason is that systems with border adjustments may be less susceptible to international tax avoidance through profit shifting, because tax liability depends not on where profits are made, but on where sales are made. ${ }^{25}$ As discussed earlier, the evolution of corporate taxes in recent decades toward lower statutory tax rates may in part be a response to the ability of corporations to shift profits. This issue does not go away in moving from a capital income tax to a consumption tax, because profits are still taxed.

\section{E. Progressivity}

On an annual basis, consumption taxes are almost certainly less progressive than income taxes, because the share of income consumed falls as income rises. If we are willing to take a longer view, though, this conclusion is less clear-cut, because the consumption-income ratio doesn't fall as much with income when both are averaged over several years. ${ }^{26}$ But consumption taxes can't possibly deliver as much progressivity as income taxes without being assessed at least

\footnotetext{
${ }^{23}$ Arguing that the proposed system was economically equivalent to a VAT plus other taxes and subsidies, the report (President's Advisory Panel on Federal Tax Reform, 2005, p. 171) indicated a belief that the system 'should be border adjustable.' But it is not clear that this belief is well-founded in law.

${ }^{24}$ Auerbach (2006a) discusses this conclusion, which is generally accepted by economists and few others.

${ }^{25}$ See Weisbach (2000).

${ }^{26}$ See Poterba (1989).
} 
in part at the individual level, allowing us to adjust tax burdens to individual circumstances. This requirement rules out using certain consumption taxes, like VATs and retail sales taxes, exclusively. In numerical simulations, Altig et al. (2001) find that a particular type of progressive consumption tax has long-run distributional effects quite similar to the U.S. income tax.

And yet, there remains skepticism that a consumption tax can be progressive enough to impose the same burden on those at the top as the current income tax. ${ }^{27}$ One way to interpret this concern is that it is about those at the very top, well within the highest 2 percent that formed the top group in the analysis of Altig et al. (2001). This is also the group, in the United States, that is subject to the estate tax, which typically hits between 1 and 2 percent of decedents annually, and is responsible for a significant share of intergenerational wealth transmission. Thus, the concern about the progressivity of the consumption tax may ultimately reflect concern about intergenerational wealth transmission. This is particularly the case in the United States, where a large fraction of the assets for families not at the very top of the wealth or income distribution are already held in some tax-sheltered form, be it housing or pension saving. ${ }^{28}$

\section{F. Consumption taxes: a summary}

Consumption taxes aren't as different from income taxes as some people think. This makes it plausible that we might replace an income tax with a consumption tax. But it also means that if we do shift to a consumption tax, we will still have many of the problems of the income tax, while exchanging other problems for new ones. We also may be constrained in our

\footnotetext{
${ }^{27}$ Moreover, whereas progressivity at the bottom of the income distribution can be dealt with on the expenditure side as well or better than through the tax system, this is not really on option at the top of the income distribution.

${ }^{28}$ For the United States in 2004, according to the Federal Reserve Board's Survey of Consumer Finances, primary residences and retirement accounts represented 74 percent of the net worth of families in the bottom 90 percent of the income distribution and 89 percent of net worth of families in the bottom 90 percent of the net worth distribution.
} 
choices by existing international agreements, and have not fully resolved the question of how to deal under the consumption tax with large accumulations of wealth. In the end, a full shift to consumption taxation may not be as attractive as it once may have seemed.

\section{Some modest proposals}

Eliminating capital income taxes is not a viable option, and a complete replacement of the income tax with some form of consumption tax may not make sense, either. But there are other options.

\section{A. The rich are different}

Much of the difficulty of adopting a consumption tax involves how we treat corporations and high-income individuals. So, we can make the transition a lot simpler by keeping them under the current tax system and adopting a consumption tax for everyone else who, as discussed earlier, don't face much capital income taxation anyway. This, in essence, is what Graetz (2002) has proposed. Replacing income taxes on low and middle-income individuals with a VAT, one would maintain income taxes on higher-income individuals and the entire corporate tax structure, thereby maintaining progressivity and not upsetting the apple cart of international tax arrangements. At the same time, the VAT would allow a reduction in remaining capital income tax rates, and therefore would lessen all the problems of the current system that relate to the level of marginal tax rates, such as corporate financial choices and international profit shifting. This may be a simpler option for the United States, which currently has no VAT, than for other countries, which would need to raise existing VATs to relatively high levels. More generally, countries can contemplate similar actions on a smaller scale, introducing or increasing the rate of the VAT and using the revenue to reduce marginal capital income tax rates. 


\section{B. A little bit of this, a little bit of that...}

It is always more exciting to think about tax reform in the large than in the small, but much may be accomplished through piecemeal reforms that attack particular problems of existing systems of capital income taxation.

\section{Corporate tax reform}

Many of the most serious distortions associated with the corporate tax arise from the distinction between debt and equity finance, and there are a variety of options to reduce this distinction within the context of existing tax systems, ranging from the imputation and split-rate systems that have been used in practice to reduce the tax burden on equity and other proposals that would alter the taxation of both debt and equity, such as the Comprehensive Business Income Tax (CBIT) that would eliminate corporate interest deductions and individual-level taxes on debt and equity. ${ }^{29}$ I have long felt that such approaches are flawed in one respect, that they provide large and unnecessary windfalls to existing capital. By reducing the tax on returns to new equity, rather than to all equity, one can do better, and schemes exist to do just that. ${ }^{30}$

Whatever reforms are directed at corporate source income, it makes sense that tax reductions should occur at the corporate level, rather than at the shareholder level, given the greater mobility of corporations and their income.

\section{Capital gains tax reform}

According to the OECD, only three of the G-7 countries (Italy, the U.S., and the U.K.) even attempt to collect individual taxes on capital gains. Where taxes are collected, they are imposed on realization, an artifact of an earlier time when asset markets weren't nearly as

\footnotetext{
${ }^{29}$ The CBIT proposal was developed by the U.S. Treasury (1992) but has never been implemented.

${ }^{30}$ See Auerbach, 1990, p. 114.
} 
developed as they are today and asset prices were difficult to determine. Taxing gains on accrual, perhaps at a lower statutory rate, would eliminate the so-called 'lock-in' effect that distorts realization decisions, and there is little to argue against accrual taxation in the case of securities traded in a liquid market. For other securities, alternatives exist going back to Vickrey (1939) and, indeed, the Meade Committee report (1978, pp. 133-35) to tax gains on realization in a way to simulate taxation on accrual, and these methods have been refined more recently to more fully eliminate the lock-in effect. ${ }^{31}$

To provide a complete picture, I must confess that the one recent attempt to implement such a system, in Italy, failed quite miserably and was repealed. ${ }^{32}$ I think we can do better, but then again I'm not sure of this.

\section{New life for the death tax?}

The United States has been struggling since 2001 with the question of whether to repeal its estate tax. ${ }^{33}$ It is not a popular tax, even though it typically hits fewer than 2 percent of decedents and is therefore of no direct concern to most taxpayers. It might make little sense at the moment to argue in favor of the estate tax in the United States, but I am currently not in the United States and will take a stab at it.

Taxes on estates or inheritances, like capital income taxes assessed during one's lifetime, discourage saving by reducing the returns to doing so. But there are two differences between estate taxes and ordinary capital income taxes. First, estate taxes hit all wealth, not just wealth having measured taxable income. Thus, they impose a more uniform burden on the returns to saving. This is an argument not only for estate taxes, but also for periodic wealth taxes, as a

\footnotetext{
${ }^{31}$ See Auerbach (1991), Bradford (1995), and Auerbach and Bradford (2004).

${ }^{32}$ See Alworth et al. (2003).

${ }^{33}$ Current law would repeal it for precisely one year, in 2010, before reinstating it.
} 
substitute for capital income taxes. Second, estate taxes hit not only the intentional bequests that decedents wish to leave to others, but also the unintentional bequests that arise when individuals hold assets to protect against possible expenses but die without encountering such expenses. Economists view such unintended bequests as evidence that annuity markets don't work as well as they should, but when unintended bequests occur, they have a very nice property from the tax authority's perspective: because they are unintended to begin with, they shouldn't be deterred by the prospect of taxation. ${ }^{34}$

A third advantage of estate taxes, relative to some other capital income taxes, is that they are on persons, not corporations. As long as national residence is not highly responsive to taxation, this focus on individuals substantially reduces one possible type of tax avoidance.

Estate taxes have their disadvantages as well, in particular the fact that they provide strong incentives for transfers of assets among related parties in a way that annual capital income taxes do not, assuming that the parties are in similar marginal tax brackets. But, from some initial thinking on the subject, I believe that there may be ways of attacking this problem. It's worth a try, at least.

\section{Conclusions}

Capital income taxes are still with us. In some sense, they always will be, given that consumption-tax alternatives preserve many attributes of capital income taxation. We have learned that the sharp distinction that Pechman and others drew between income taxes and consumption taxes is overly strong, and that it makes little sense to be in favor of one approach or the other without getting into details. Some elements of consumption taxation are attractive,

\footnotetext{
${ }^{34}$ Taking this factor into account, Kopczuk (2003) estimates that the estate tax is not necessarily less efficient than the general income tax. This is noteworthy given that estate tax payments are so highly concentrated among the wealthy.
} 
particularly in light of how much individual capital income now escapes taxation. But we probably also need to think harder about what happens at the top of the income distribution, where the difference between income and consumption taxes takes on greater importance, and where income concentration has been growing in many countries, including both the United Kingdom and the United States. ${ }^{35}$

${ }^{35}$ See Piketty and Saez (2006). 


\section{References}

Altig, D., A.J. Auerbach, L.J. Kotlikoff, K.A. Smetters, and J. Walliser (2001), 'Simulating fundamental tax reform in the United States,' American Economic Review, vol. 91, pp. 574-595.

Alworth, J., G. Arachi, and R. Hamaui (2003), "What's come to perfection perishes": adjusting capital gains taxation in Italy,' National Tax Journal, vol. 56, pp. 197-219.

Altshuler, R., and H. Grubert (2005), 'The three parties in the race to the bottom: host governments, home governments and multinational companies,' unpublished paper, March 24.

Atkinson, A.B., and J.E. Stiglitz (1976), 'The design of tax structure: direct versus indirect taxation,' Journal of Public Economics, vol. 6, pp. 55-75.

Auerbach, A. J. (1983), 'Corporate taxation in the United States,' Brookings Papers on Economic Activity, vol. 1983, pp. 451-513.

Auerbach, A. J. (1986), 'The dynamic effects of tax law asymmetries,' Review of Economic Studies, vol. 53, pp. 205-225.

Auerbach, A.J. (1990), 'Debt, equity, and the taxation of corporate cash flows,' in J. Shoven and J. Waldfogel (eds.), Debt, Taxes, and Corporate Restructuring, Washington: Brookings Institution.

Auerbach, A.J. (1991), 'Retrospective capital gains taxation.' American Economic Review, vol. 81, pp. 167-178.

Auerbach, A. J. (2006a), 'The choice between income and consumption taxes: a primer,' NBER working paper 12307, June.

Auerbach, A. J. (2006b), 'Why have corporate tax revenues declined? Another look,' NBER working paper 12463, August.

Auerbach, A.J., and D.F. Bradford (2004), 'Generalized cash-flow taxation,' Journal of Public Economics, vol. 88, pp. 957-980.

Auerbach, A. J., and J. Slemrod (1997), 'The economic effects of the tax reform act of 1986,' Journal of Economic Literature, vol. 35, pp. 589-632.

Becker, J., and C. Fuest (2005), 'Does Germany collect revenue from taxing capital income,' CESifo working paper 1489, June. 
Boadway, R., and N. Bruce (1984), 'A general proposition on the design of a neutral business tax,' Journal of Public Economics, vol. 24, pp. 231-239.

Bond, S.R., and M.P. Devereux (1995), 'On the design of a neutral business tax under uncertainty,' Journal of Public Economics, vol. 58, pp. 57-71.

Bond, S., M. Gammie, and S. Mokkas (2006), 'An Economic Assessment of the Role of the ECJ,' paper presented to the European Tax Policy Forum/Institute for Fiscal Studies conference on The Impact of Corporation Tax Across Borders, London, April.

Bradford, D.F. (1995), 'Fixing realization accounting: symmetry, consistency and correctness in the taxation of financial instruments,' Tax Law Review, vol. 50, pp. 731-785.

Bradford, D.F. (1998), 'Transition to and tax rate flexibility in a cash-flow type tax,' in J. Poterba (ed.), Tax Policy and the Economy, vol. 12, pp. 151-172.

Chamley, C. (1986), 'Optimal taxation of capital income in general equilibrium with infinite lives,' Econometrica, vol. 54, pp. 607-622.

Comin, D., and T. Philippon (2005), 'The rise in firm-level volatility: causes and consequences,' in M. Gertler and K. Rogoff (eds.), NBER Macroeconomics Annual, pp. 167-201.

Devereux, M.P., R. Griffith and A. Klemm (2002), 'Corporate income tax reforms and international tax competition,' Economic Policy, vol. 35, pp. 451-495.

Diamond, P.A., and J.A. Mirrlees (1971), 'Optimal taxation and public production I: production efficiency,' American Economic Review, vol. 61, pp. 8-27.

Gordon, R. H., and J.R. Hines, Jr. (2002), 'International taxation,' in A. Auerbach and M. Feldstein (eds.), Handbook of Public Economics, vol. 4, Amsterdam: NorthHolland/Elsevier.

Gordon, R., L. Kalambokidis, and J. Slemrod (2004), 'Do we now collect any revenue from taxing capital income?' Journal of Public Economics, vol. 88, pp. 981-1009.

Graetz, M.J. (2002), '100 million unnecessary returns: a fresh start for the U.S. tax system,' Yale Law Journal, vol. 112, pp. 261-310.

Graetz, M.J., and A.C. Warren, Jr. (2006), 'Income tax discrimination and the political and economic integration of Europe,' Yale Law Journal, vol. 115, pp. 1185-1255.

Institute for Fiscal Studies (1978), The Structure and Reform of Direct Taxation, London: Allen and Unwin.

Judd, K.L. (1985), 'Redistributive taxation in a simple perfect foresight model,' Journal of Public Economics, vol. 28, pp. 59-83. 
Kopczuk, W. (2003), 'The trick is to live: is the estate tax social security for the rich? Journal of Political Economy, vol. 111, pp. 1318-1341.

Pechman, J. A. (1990), 'The future of the income tax,'American Economic Review, vol. 80, pp. $1-20$.

Piketty, T., and E. Saez (2006), 'The evolution of top incomes: a historical and international perspective,' American Economic Review, vol. 96, pp. 200-205.

Poterba, J.M. (1989), 'Lifetime incidence and the distributional burden of excise taxes,' American Economic Review, vol. 79, pp. 325-330.

President's Advisory Panel on Federal Tax Reform (2005), Simple, Fair, and Pro-Growth, Washington: U.S. Government Printing Office.

Slemrod, J. (1992), 'Do taxes matter? Lessons from the 1980's' American Economic Review, vol. 82 , pp. $250-256$.

Sørensen, P. B. (2006), 'Can capital income taxes survive? And should they?' paper presented to the CESifo Venice Summer Institute workshop on The Future of Capital Income Taxation at Venice International University, July.

U.S. Department of the Treasury (1992), Integration of the Individual and Corporate Tax Systems, Taxing Business Income Once, Washington: U.S. Government Printing Office.

Vickrey, W. (1939), 'Averaging of income for income tax purposes,' Journal of Political Economy, vol. 47, pp. 379-397.

Weisbach, D.A. (2000), 'Ironing out the flat tax,'Stanford Law Review, vol. 52, pp. 599-664.

Wilson, J.D (1999), 'Theories of Tax Competition,' National Tax Journal, vol. 52, pp. 269-304.

Zodrow, G. R. (2005), 'Should capital income be subject to consumption-based taxation?' paper presented to the Tax Policy Center/American Tax Policy Institute/Tax Analysts conference on Taxing Capital Income, Washington, September. 

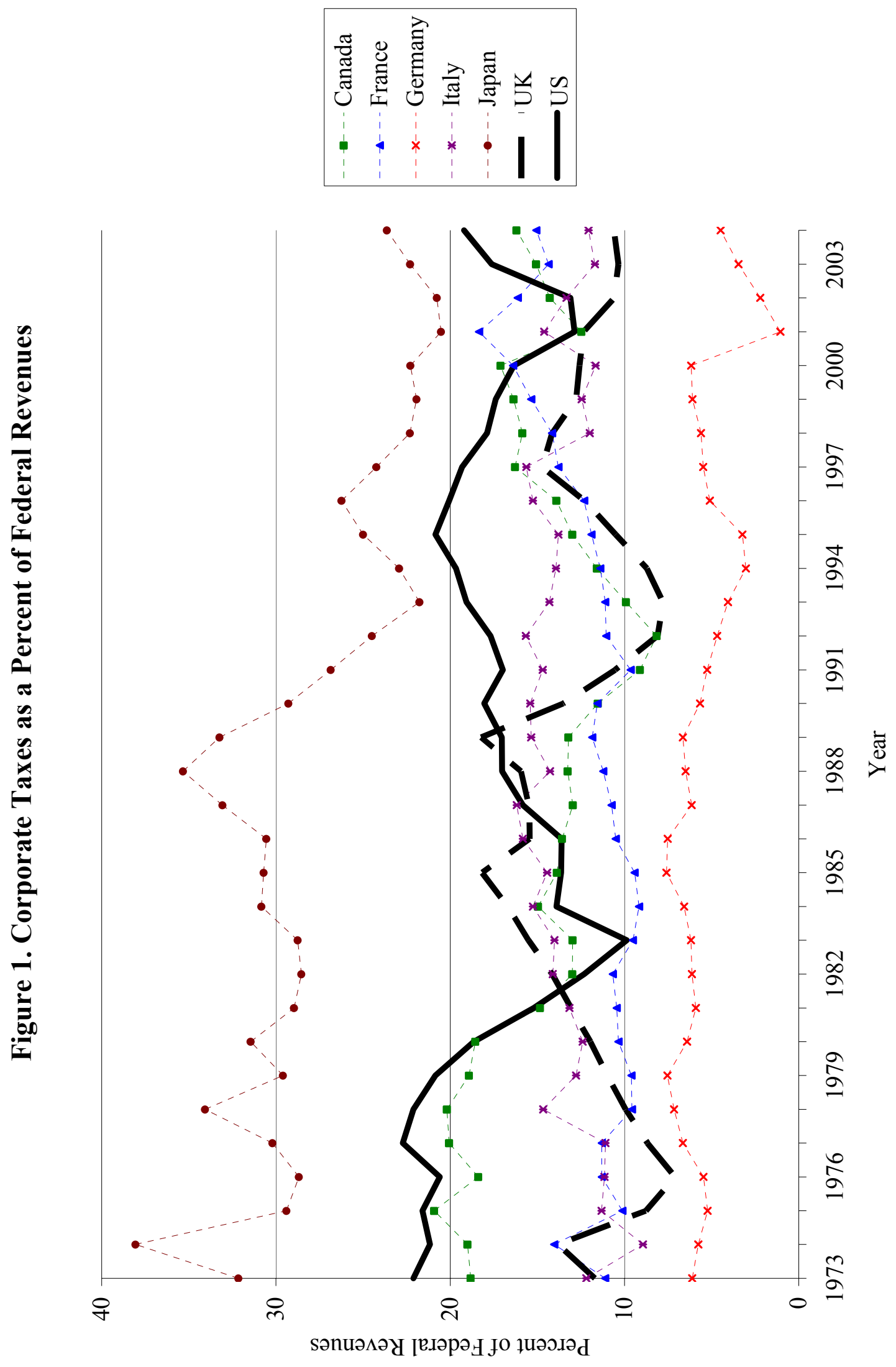

0
Iิ
0
0
0
0
0 

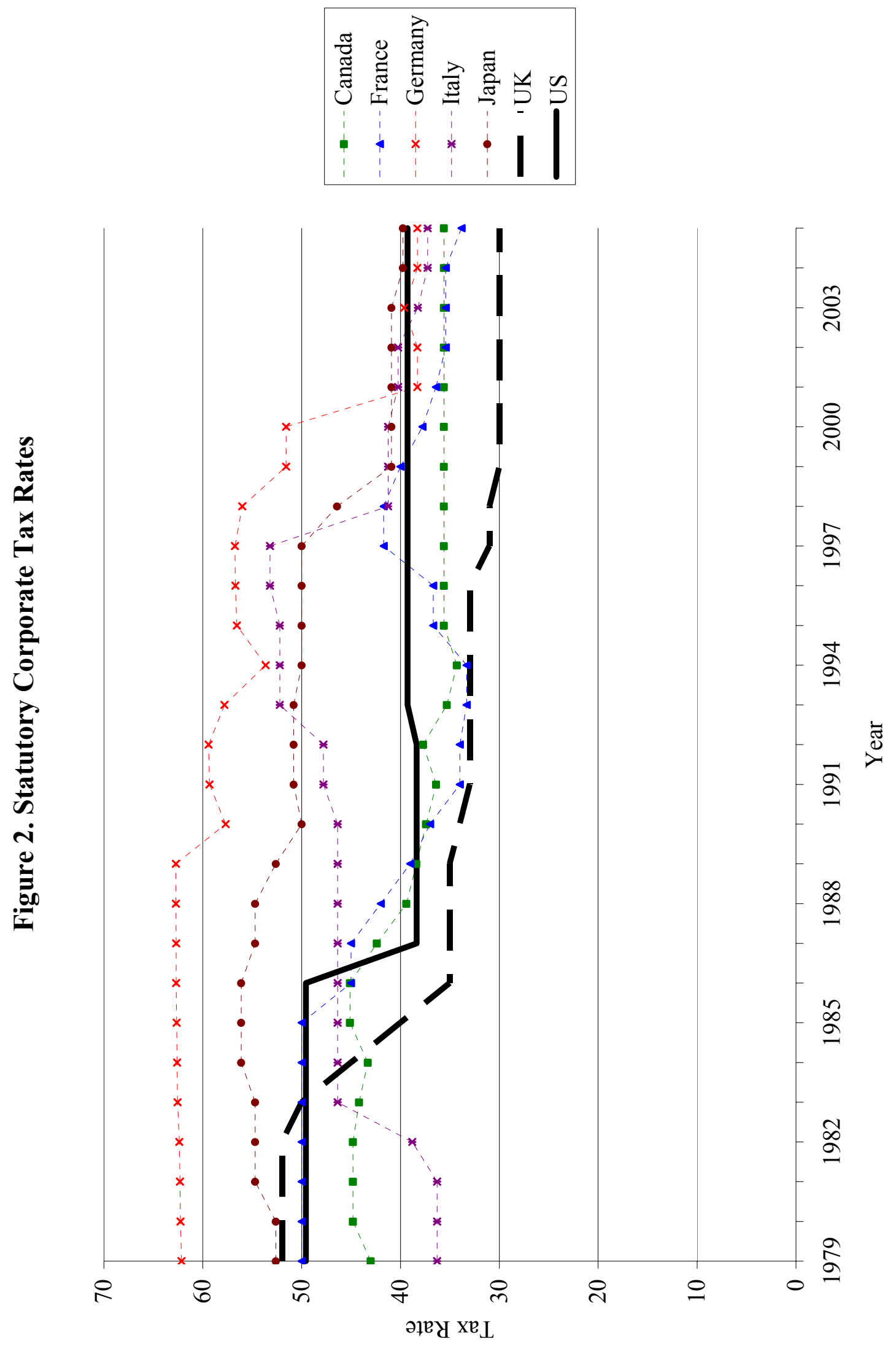

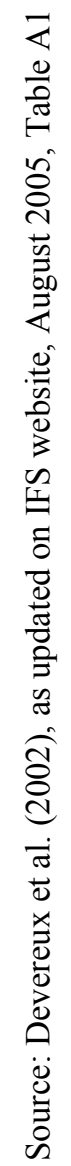




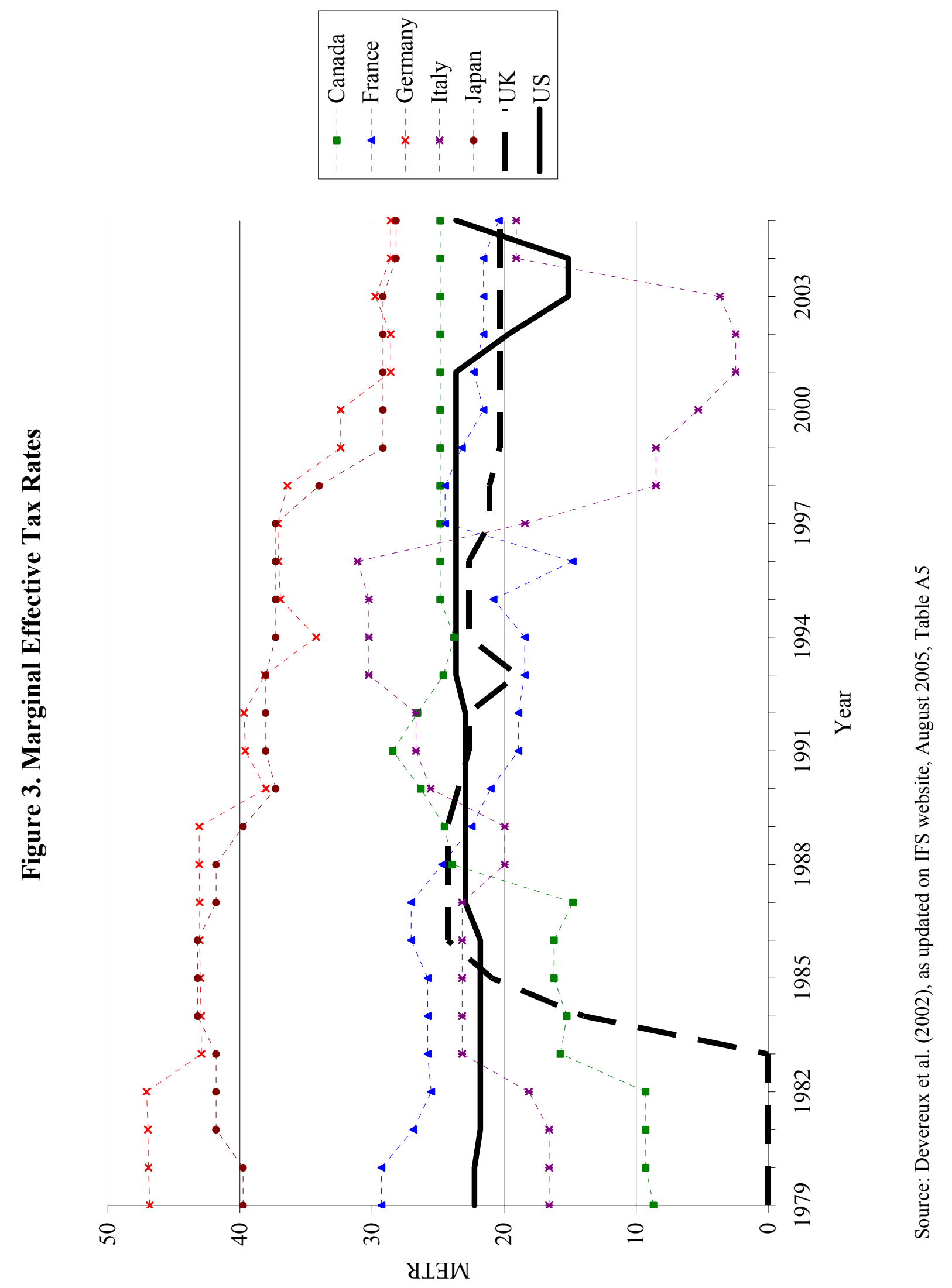




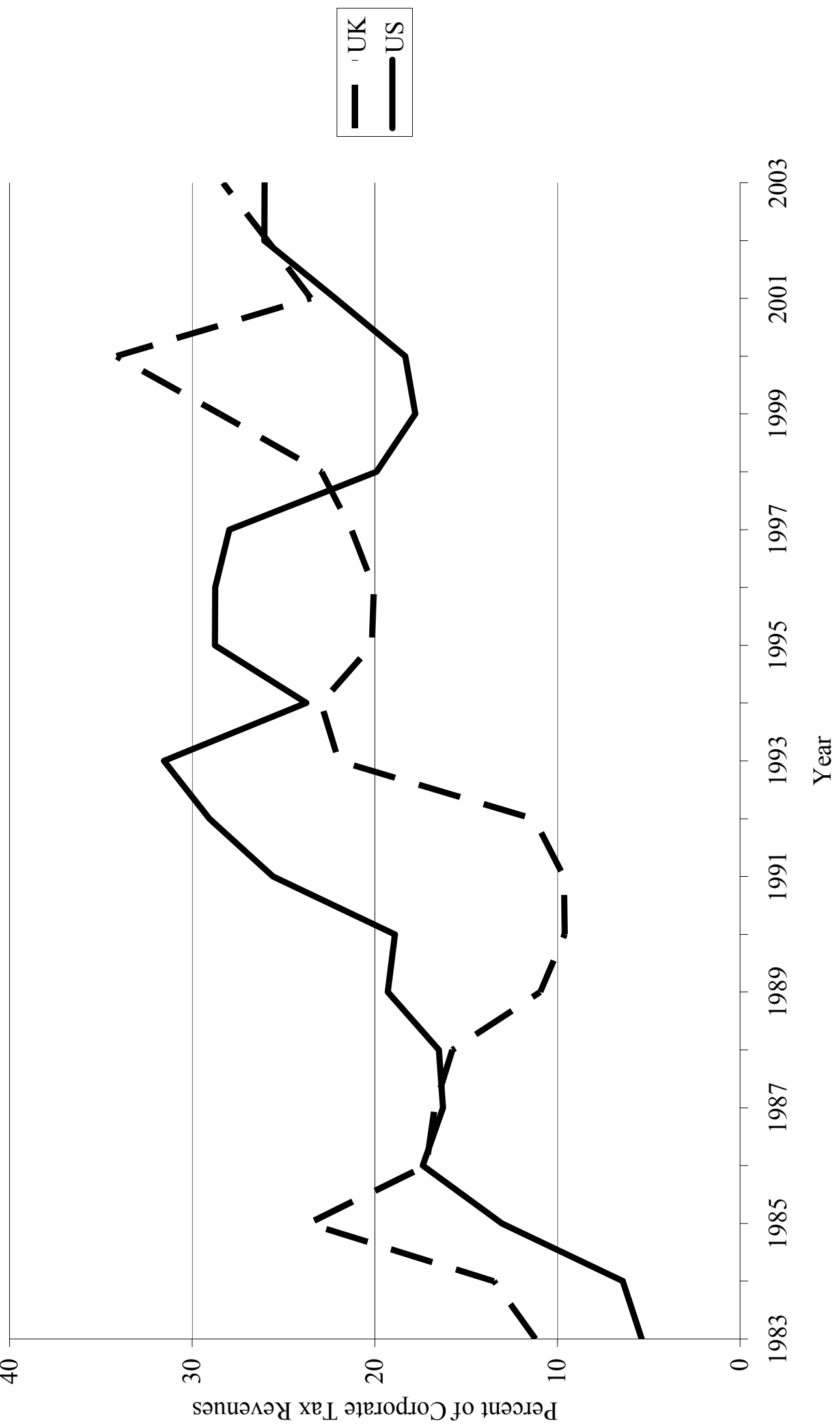

告 


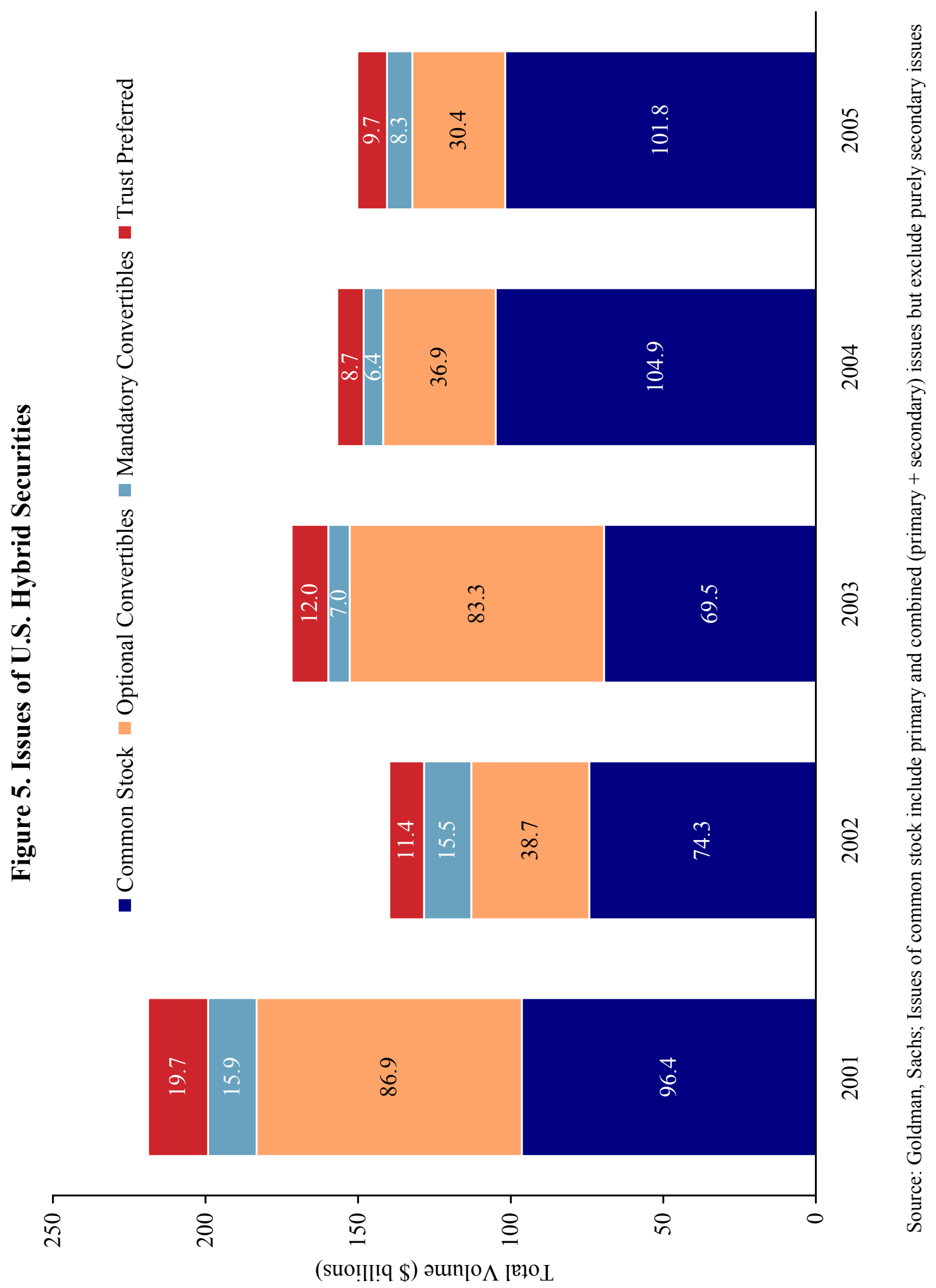



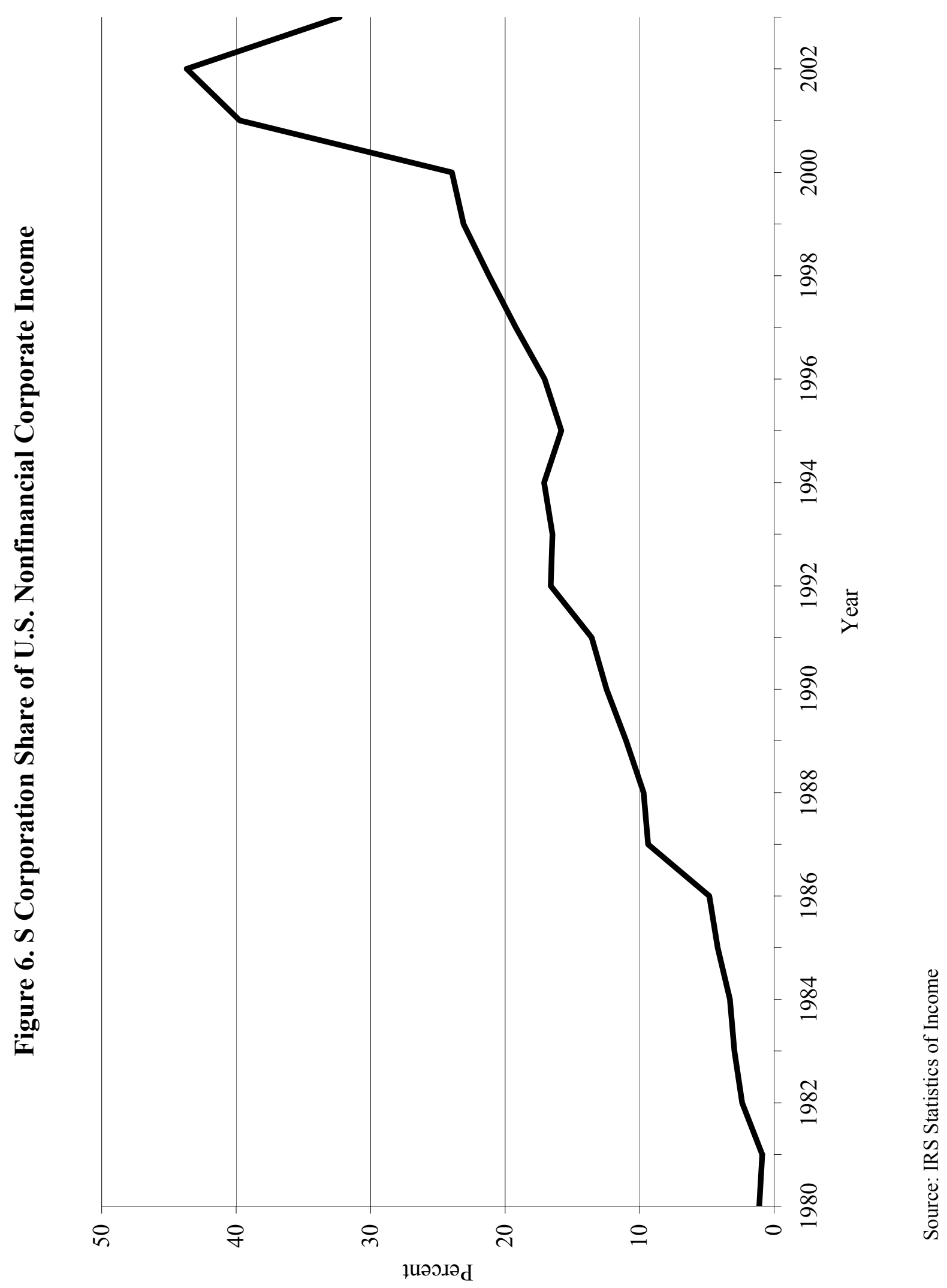


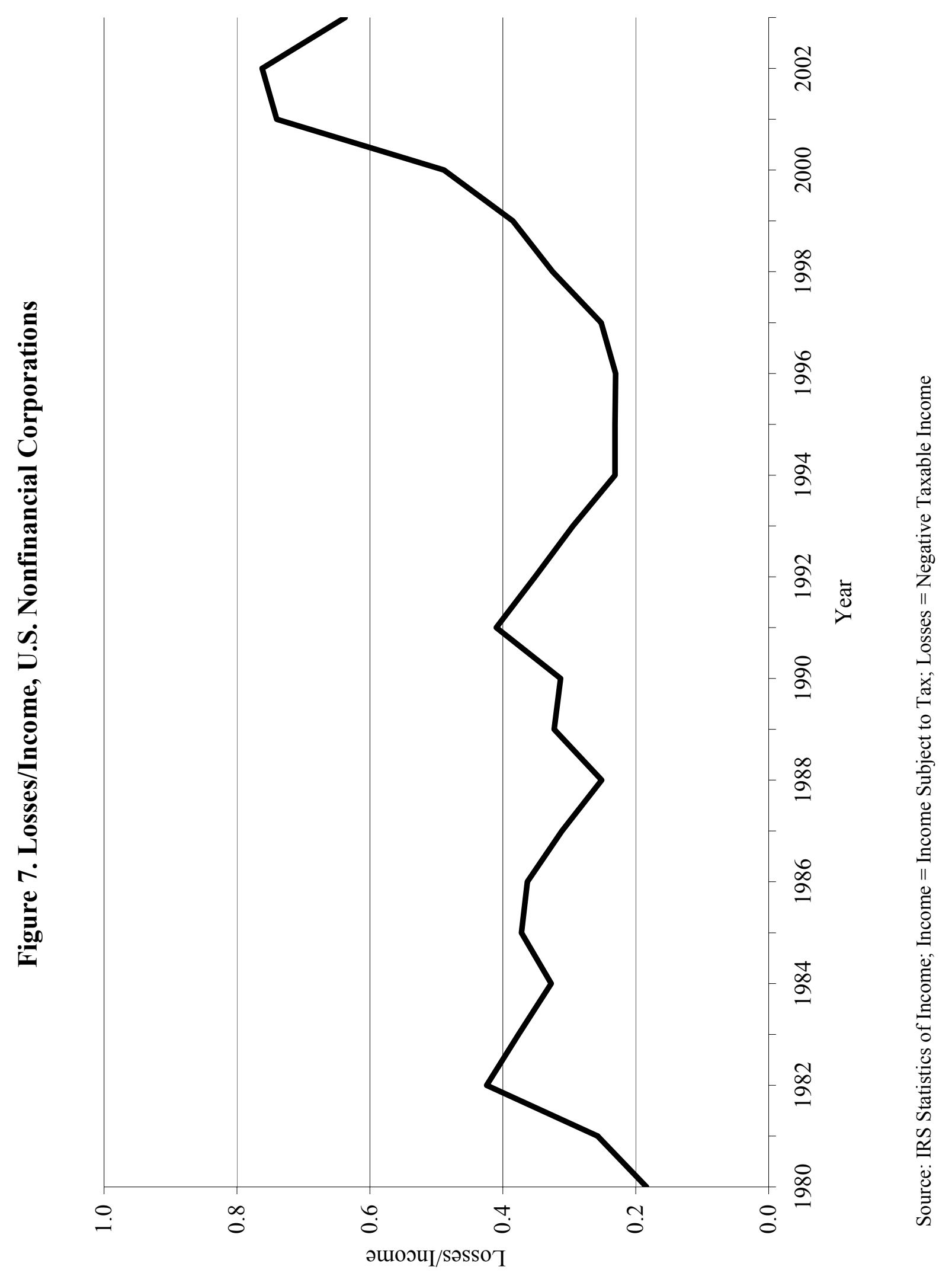

